\title{
The changing use-cases of medium and large-scale geological maps in Hungary
}

\author{
Gáspár Albert ${ }^{\mathrm{a}, *}$ \\ ${ }^{a}$ ELTE Eötvös Loránd University, Department of Cartography and Geoinformatics, albert@ludens.elte.hu, \\ * Corresponding author
}

\begin{abstract}
Systematic geological mapping of a country is done mainly by state authorities often involving industrial and academic partners in the process. The resolution of the result is controlled primarily by the financial background of the firms and the scale of the available base maps. In Hungary the state authority for geological mapping was established in 1869. Prior to this, geological maps were aimed to give an overview of the country. Later the mapping campaigns focused on providing support for the industry, agriculture and civil engineering. The need for detailed maps of raw materials led to increased efforts and founding, but from the end of the 1970s the mining industry did not need more maps and the geological mapping campaigns lost their inertia. Parallel with this, in the Cold War era, the ban to use detailed topography on geological maps ruined the ergonomic value of the produced cartographic materials. After the collapse of the socialist economy in 1989 the state authority concentrated on digitizing the existing data instead of systematic geological mapping. Geological maps became an illustration of extensive contributed books about certain regions, which were made by scientists for scientist. Though, many of these medium-scale geological maps are now provided via internet, large-scale maps are not available. In the last decade, the use-case of the geological maps seem to be changing again. The geological information interests not only the professionals, but the larger audience as well. Also, the spreading of geotourism, created a need to compile geotourist maps.
\end{abstract}

Keywords: geological maps, map use, map-design, geotourist maps, geology of Hungary

\section{Introduction}

The aim of the geological mapping is to gather information about the materials and geological processes (Compton, 1985). This information is usually important for the mining industry, but recently the tourism also exploit it as new destinations can be identified with the help of geological maps (Hose, 1996).

In the early $19^{\text {th }}$ century, at the dawn of modern geology, maps became a visual language for geologists (Lyell, 1830; Eyles, 1972; Rudwick, 1976). The geological content was drawn generally on the contemporary topographic maps and the improvement of such base maps made it possible to use the geological maps to disseminate the geological knowledge (Rudwick, 1976). James Hutton's and William Smith's mapping method became widespread and a standard for their followers (Dean, 1992), but with maps using the ancient and crude representation of hypsography as "mole hills", the visual language of geology would never have emerged. The evolution of topographic mapping and the increasing resolution of publicly available topographic data was a key factor in the usability of geological maps.

\subsection{Topographic map series as the base for systematic} geological mapping

The mapping scale for geologists is determined by the base map they can use. This means that the point-like observations on the field are put on the most detailed map available, and the geological settings in between them is predicted as accurately as possible in that scale (Compton, 1985). While the field-work is done on the largest available scale, the interpretation of the geology is usually compiled on medium scale maps.

In Hungary the earliest geological maps were drawn on medium-scale topographic maps using ancient techniques for visualizing the morphology (Townson, 1797; Beudant, 1823). The first generation of mapping geologists in the region (e.g., J. Pettkó, J. Szabó, W. Haidinger, M. Hantken, F. von Hauer) emerged only in the middle of the $19^{\text {th }}$ century and worked on more precise contemporary topographic base maps (Brezsnyánszky, 1996). At this time the Austrian Empire already compiled as large as 1:28 800 scale topographic maps, but for the public only the generalised versions, the 1:144 000 and 1:288 000 maps were available (Kretschmer et al., 2004).

By the advancing technological and industrial discoveries in the $19^{\text {th }}$ century, it soon became a necessity for the state to do regular geological surveys of the country and state geological mapping authorities (GMAs) were established for this task (Brezsnyánszky, 1996).

The first geological mapping campaigns of the GMAs aimed to cover the whole country systematically and were determined by the largest available scale of base maps. Even in a medium scale, this means several dozens of maps. Thus, a synthesis was needed after the mapping campaign has been finished. Such synthesis is usually performed as a compilation of a medium or small scale geological map of the area (Rudwick, 1976). 


\subsection{The driving forces of the changing use-cases of geological maps}

The cycles of systematic mapping and elaboration of synthesis maps are characteristically outlined the history of Hungarian geological maps. The scale of the maps generally increased, and the main purpose of the mapping campaigns has changed in each cycle.

The maps of each era represent certain aims that were defined by the chief geologists of the mapping campaigns. Also, the use-cases of the maps are determined by these aims. The change of the aims and use-cases more-or-less reflects the change of society's view of geology. Since the general view is changing as peoples' knowledge and accessibility to information increase, the use-cases of geological maps also change.

\subsection{About this paper}

This paper highlights the differences of aims in the sequence of mapping campaigns, and gives an overview about the evolution of Hungarian geological maps. Ever while the accumulation of detailed geological information is continuous, the elaboration of geological maps in increasing details is needed. Since the geological mapping is still present in Hungary, and the society's view of geology - and geoscience in general - is changing ${ }^{1}$, new use-cases of geological maps also emerge. The aim of this paper is to highlight the currently changing nature of geological map use and to introduce the possible new forms of geological maps of the near future.

Such summary was not published before about this topic. It is also without precedence to sketch up a possible trajectory of the evolution of geological map use in the future.

\section{The first systematic mappings in the $19^{\text {th }}$ century}

By the time, when the Royal Hungarian Geological Institute was established in 1869 , the $2^{\text {nd }}$ Military Topographic Survey of the Habsburg Empire was almost finished. Although the survey scale was 1:28 800, maps were published in medium (144k and 288k) scale for the public use $^{2}$ (Kretschmer et al., 2004). Manuscripts of the first systematic geological mapping campaigns were prepared on these sheets (Figure 1). The chief geologists, such as Wilhelm Haidinger, Franz von Hauer, József Szabó and János Böckh were focusing mainly on the stratigraphy. The first GMA was the Austrian Geological Institute (from 1849), but universities in Pozsony, Pest, Brasso, and from 1869 the Hungarian GMA (Royal Geological Institute) were also involved in the campaigns of systematic mappings. The main objective was to acquire general geological information from the whole country, which was the Austrian Empire at that time (Brezsnyánszky, 1996).

From the aspect of the contemporary people, the $144 \mathrm{k}$ maps were the most detailed maps ever seen of their

\footnotetext{
${ }^{1}$ Basic geoscientific knowledge is crucial to effectuate several of the UNESCO Sustainable Development Goals, which is approved by Hungary (VNRH, 2018). Such knowledge can
}

country, and there was a need to generalize this detailed information to see the overall settings of the geology in the region. The synthesis of the mapping campaigns was first elaborated as maps and monographs about distinct parts of the Austrian Empire (e.g., Kóródi et al., 2016). Finally the geological overview map of the whole country was compiled in 1864 and published in 1867 as a 567k map series of 12 sheets (von Hauer, 1867). With an explanatory book describing 102 different geological formations, the first synthesis of the acquired information provided a solid background for the subsequent mapping campaigns.

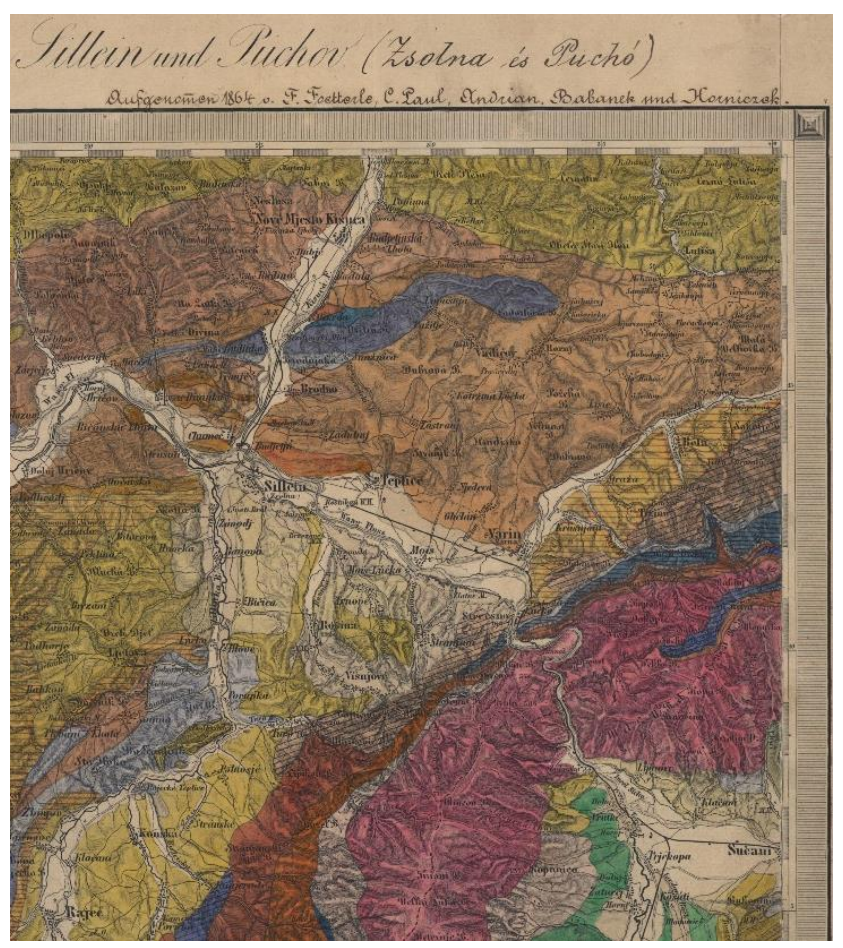

Figure 1. Excerpt of the 144k survey sheet F2 (Sillein and Puchov villages) compiled in 1864 . The geological theme was handdrawn over the topographic content (from the archives of the Hungarian Geological Reference Library, item no. 18 II/b).

\subsection{Undisclosed topographic maps}

The 1:144 000 geological map series was not published about the whole country, because shortly after the geological mapping has started, the $3^{\text {rd }}$ Military Topographic Survey of the Habsburg Empire emerged, providing a more detailed 1:75 000 map series for public use (Pentelényi \& Síkhegyi, 2012). This new base map was already using the new metric measure system and contained contour lines (besides using the slope hatches) for representing the hypsography (Zentai, 2018). Field geologists still not profited much from this new way of visualizing the $3^{\text {rd }}$ dimension, because the working scale (1:75 000) was not large enough to make precise compilations from point observations. The old materials of the $2^{\text {nd }}$ Military Topographic Survey in 1:28 800 scale were undisclosed and used for some area of the country,

give people a different aspect of view about geology putting it in a more environmentally conscious context.

2 The survey maps were disclosed, and remained in manuscripts. 
but having slope hachures instead of contours the fieldwork was very problematic on mountainous terrains (Tóth-Makk, 1994).

The aim to cover the whole country with a series of geological maps having a uniform key system was pointed out right from the beginning (i.e., the establishment of the Royal Hungarian Geological Institute in 1869). However, the mapping campaigns soon diverged into two directions because of the country's geological settings: 1) mapping of the mountains and hills, and 2) the lowlands. The first option was preferred from the geological aspect although, a huge portion of the country belonged to the other category (Figure 2).

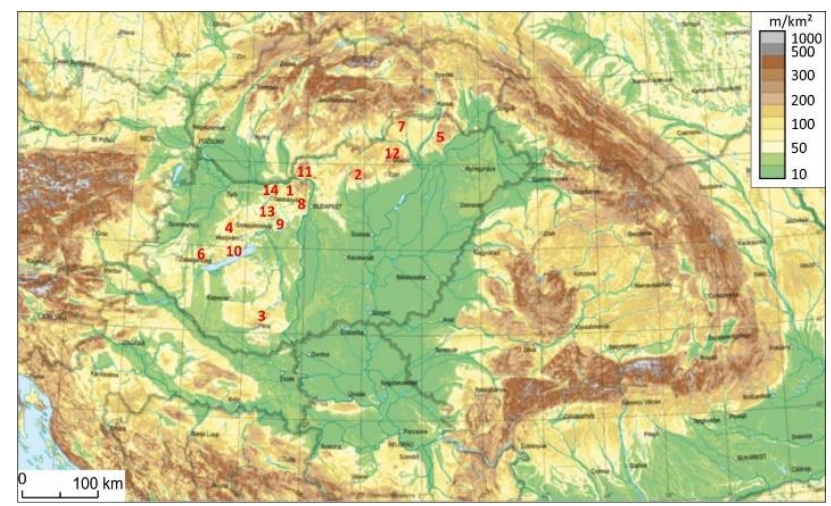

Figure 2. Relative heights in the Carpathian-Pannonian region which was the main working area of the Royal Geological Institute of Hungary (based on Gábris et al., 2018). Numbers indicate the regions of Table 1 and 2.

Those, who worked on the lowlands recorded the soil structures together with the sediments, and made agrological overlays on the field maps. This was the time of the emergence of a new discipline, the pedology (soil science) which was an attractive option for the new generation of geoscientists (e.g. Heinrich Horusitzky, Béla Inkey, Péter Treitz). They became the first agrogeologists of the Geological Institute in 1891 when the Agrogeological Department was established (Szabó-Kele et al., 2010).

\subsection{Synthesis of the first Hungarian geological mapping campaign}

A synthesis map of the geological knowledge about the territory of Austria-Hungary was compiled as early as 1845 (Brezsnyánszky, 1996). It summarized the results of the previous geological mappings and contained only 22 geological categories. The second synthesis in 1867 was mainly based on a more detailed 144k survey, but the lowlands were not processed systematically. The more detailed 75k survey - done by Hungarian geologists of the Royal Geological Institute of Hungary - manifested as a 1:1 000000 map in 1896 and was exhibited in a larger, 360k scale at the World Expo 1900 in Paris (Böckh et al., 1896). Its renewed and completed version was republished in 1922 (Figure 3). It already used the colouring schemes of the stratigraphic units which was outlined on the $2^{\text {nd }}$ international geological congress in Bologna (Renevier, 1881).

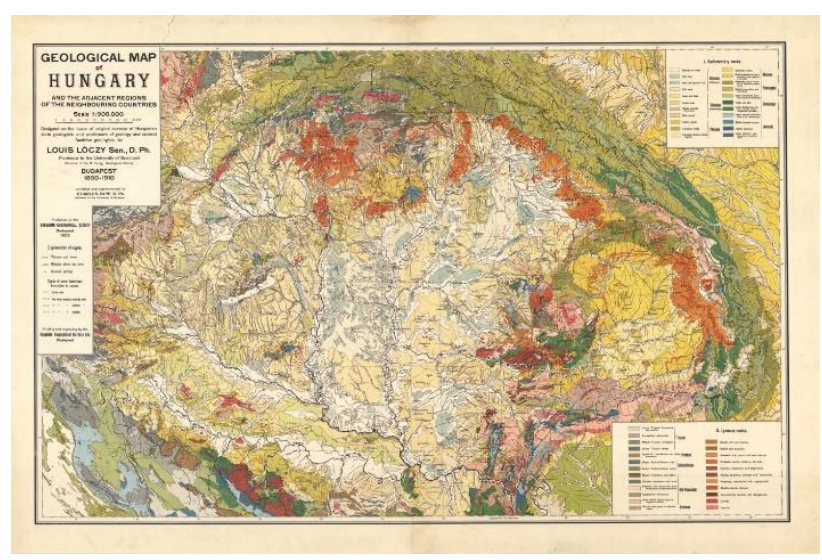

Figure 3. The renewed and completed synthesis map was published in 1:900 000 (Lóczy \& Papp, 1922).

\section{Mapping of the rocks or soils}

Hungary was one of the first country in the world, where the importance of soil sciences was recognized. After the first International Congress of Soil scientists in 1909 - held in Budapest, the capital city of Hungary - it earned moral and financial support from the decision makers, and a new mapping policy was worked out. Until this time field geologists were simultaneously focusing on the geological and soil characteristics of the surface during mapping campaigns, but from 1909 the two procedures were separated (Szabó-Kele et al., 2010).

\subsection{Increasing the scale to 1:25 000 and more}

The collapse of the Austrian-Hungarian Monarchy in 1919 resulted the separation of state topographic mapping resources between the new countries. In 1920, soon after that the Hungarian topographic mapping authority (Hungarian Military Mapping Group) was established, the disclosed manuscript maps of the previous topographic surveys became available for military, civil and scientific use as well (Jankó, 2018).

In the first decades of the 20th century the discipline of geomorphology has spread among geologist working with unconsolidated sediments (e.g., Oldroyd \& Grapes, 2008). For them the morphology of the mapped area become increasingly important and the newly obtained maps contained invaluable information about the hypsography of the whole country. The most detailed data about the morphology was collected during the 3rd Military Topographic Survey from 1869-1887, and was uniformly compiled on 1:25000 map sheets. Its renewed versions containing no slope hachures but only contours with $2.5 \mathrm{~m}$ intervals were available from 1924 (Jankó, 2018). These maps largely facilitated the fieldwork of geologists, who previously used $75 \mathrm{k}$ sheets containing slope hachures.

Between the two World Wars, the highly detailed topographic base maps gave a boost of all kinds of thematic mapping, and geological maps of various locations and scales were compiled in large quantities (Vitális, 1993). These mapping activities were always coordinated by certain chief geologists (e.g., Lajos Lózcy sr., Elemér Vadász, József Sümeghy), but sometimes used very different key system for the geological formations 
especially after 1931 (Fülöp, 1968). The aim was to acquire as detailed surface data of certain (particularly mining) regions as possible. The Geological Institute established a press to print the large amount of maps created by its geologists (Pentelényi \& Síkhegyi, 2012). Also, this was the time when the trenching and welllogging became organic part of a geological mapping campaign to assist the understanding of the spatial parameters of known geological formations (Fülöp, 1968). The $25 \mathrm{k}$ topographic maps and the precise hypsography made it possible to do more precise predictions for spatial extents of the geological formations by using means of geometry.

The most coordinated countrywide geoscientific surveying activity was the agrogeological mapping in $25 \mathrm{k}$ scale at this time (Kreybig, 1937). By its completion, in the early 1950 s, Hungary was the first country in the world to have collected such detailed soil information for the whole country (Pásztor et al., 2012).

\section{Industrial mapping (1:10 000)}

The well-known resources of industrial minerals fell outside the reduced territory of Hungary after the Trianon Treaty in 1920 (Vitális, 1993). It was crucial to find new quarries of raw materials (especially coal and metals) for the industry within the new boundaries of the country. Coordinated and less coordinated campaigns shaped the outlines of the geological mapping activity between the two World Wars and in the WW 2 the geological mapping completely ceased (Fülöp, 1968).

The Geological Institute of Hungary after the $2^{\text {nd }}$ WW concentrated on the research of raw materials to assist the socialist economy in making the country's heavy industry stronger. Although agrogeological research remained present, the soil mapping was separated from the Geological Institute and assigned to the Research Institute for Soil Science and Agricultural Chemistry (Várallyay, 1989).

From the beginning of the 1950s the new generation of field geologist has started to work for one of the three main employers of geoscientists: 1) oil and gas industry, 2) mining industry, 3) state geological survey. The latter was the Geological Institute of Hungary, which stored the maps of more than 100 years of geological mapping in its archives by this time.

\subsection{Focusing on hills, basins and depths}

The most detailed topographic base map of the country was still the $25 \mathrm{k}$ map series in 1950 . Based on the huge archive data, a renewed geological map series was compiled in 1953 in $25 \mathrm{k}$ scale form the mountainous regions of the country to serve as the base of new mineral explorations (Fülöp, 1968). The new maps used a unified symbol system as well (Galambos, 2009), and also served as a base for the compilation of a new 300k synthesis map of the previously acquired knowledge (Balogh et al., 1956).
From 1955 a new state surveying campaign was initiated which provided 10k topographic maps (Szabó, 2018). This new map series was the base of the subsequent geological mapping campaigns, although the political circumstances made the use of such maps very complicated for civil and scientific purposes as the Cold War gradually escalated (Pentelényi \& Síkhegyi, 2012).

The geological surveying turned to new targets: the smaller mountain ranges and intra-mountain basins within the new country-borders, where the industrial ores and coal-bearing formations were already documented, but not fully explored (Pentelényi \& Síkhegyi, 2012). Mapping campaigns were initiated with the contribution of Soviet researchers to find raw materials (e.g. bauxite), but also to teach the new generation of Hungarian geologists how to do exploratory geological mapping (Fülöp, 1968). The results were large scale (10k) map series of several mountainous and industrial regions. At least two versions of the maps were compiled of each tiles (covered and uncovered by the Quaternary formations) to facilitate the understanding of the geological settings. Also, the maps were completed with cross-sections and small explanatory booklets (Table 1). Each map series served as the base of a synthesis map of the region in smaller scale.

\begin{tabular}{|l|l|l|l|l|}
\hline No. & Region & \multicolumn{2}{|l|}{ Issues } & Year \\
\hline & & Map & Booklets & \\
1 & Dorog Basin & 10k $(14$ pcs $)$ & 11 pcs & $1962-73$ \\
2 & Mátra Hill & 10k $(19$ pcs $)$ & 22 pcs & $1962-79$ \\
3 & Mecsek Mts. & 10k (21 pcs) & 22 pcs & $1961-76$ \\
4 & Bakony Mts. & 20k (25 pcs)* & 24 pcs & $1966-88$ \\
5 & Tokaj Hills & 25k (17 pcs) & 17 pcs & $1962-77$ \\
\hline
\end{tabular}

Table 1. Large-scale geological map series in Hungary published after 1956. The number of map sheets are indicated in brackets. Booklets were published individual. *One sheet was in $25 \mathrm{k}$.

The industrial exploration - driven primarily by the energy sector - made it possible to compile the first countrywide map of the subsurface geology in 1957 based on deep borehole and geophysical data (Kertai, 1957).

The geological mapping of the lowlands $1950-55$ provided only low resolution $\mathrm{data}^{3}$, but started the regular documentation of the water level in wells, and established the hydrogeological monitoring in the Geological Institute (Fülöp, 1968). From the 1980s the renewed mapping of the basins resulted a $100 \mathrm{k}$ geological map series of the Great Hungarian Plain (Tóth-Makk, 1994).

\subsection{Loosing inertia}

The exploratory mapping slowly lost its inertia by the end of the 1970s. One of the main reasons was the decreasing need of new regional maps from the mining industry. The most promising regions were already found, and with the technology becoming more advanced, and the scientific approaches more complex, the industrial geological explorations concentrated on smaller territories instead of regions. Also, many of the experienced field geologist were exported in the developing countries of the socialist

\footnotetext{
${ }^{3}$ The compiled maps were published as a 200k series of the Great Hungarian Plain.
} 
block (e.g., Cuba, Mongolia) to do geological surveying, and on the Hungarian regions there remained fewer of them. However, the detailed mapping of certain regions continued in a nominal scale of 1:10 000. These parts of the country were those, where the raw material-bearing formations were already known, and well explored, but with a thorough systematic mapping new scientific results may have been achieved. The large-scale map series of the target regions were usually not finished, and not published after the most important parts were compiled. However, the regional overview maps in medium (25-50k) scale provided a solution for saving the acquired knowledge as a compiled map in those cases when the detailed maps were not published (Table 2). From the end of the 1980s the publication of the detailed maps were not even considered.

\begin{tabular}{|c|c|c|c|c|}
\hline No. & Region & Sc. & $\begin{array}{l}\text { Year of } \\
\text { publish }\end{array}$ & $\begin{array}{l}\text { Book } \\
\text { pages }\end{array}$ \\
\hline 6 & Keszthely Mts. & $20 \mathrm{k}$ & 1979 & 102 \\
\hline 7 & $\begin{array}{l}\text { Aggtelek-Rudabánya } \\
\text { Hills }\end{array}$ & $25 \mathrm{k}$ & 1988 & 92 \\
\hline 8 & Buda Hills Tectonics & $25 \mathrm{k}$ & 1977 & 76 \\
\hline 9 & Velence Hills & $25 \mathrm{k}$ & 2005 & 316 \\
\hline 10 & Balaton Uplands & $50 \mathrm{k}$ & 1999 & 257 \\
\hline 11 & Börzsöny-Visegrád Mts. & $50 \mathrm{k}$ & 1998 & 216 \\
\hline 12 & Bükk Mts. & $50 \mathrm{k}$ & 2005 & 284 \\
\hline 13 & Vértes Hills & $50 \mathrm{k}$ & 2008 & 368 \\
\hline 14 & Gerecse Hills & $50 \mathrm{k}$ & 2018 & 490 \\
\hline
\end{tabular}

Table 2. Medium (25-50k) scale geological maps of the systematically mapped regions in Hungary, where the detailed large-scale (10k) maps remained in manuscripts and published explanatory books exist.

\section{The age of contributed books}

From the end of the 1980s, the Hungarian GMA slowed the pace of the field work in the country. The mapping though, was continuous, but due to the lack of financial backing, only a handful of geologist worked on mapping projects in the 1990s. The reason was: the economy (mining industry ${ }^{4}$ ) did not need any more detailed geological maps, and at that time the importance of the younger (i.e., Quaternary) formations from ecological aspects were not yet fully recognized either. The mapping campaigns resulted primarily scientific achievements, and the explanatory booklets of the maps gradually increased in volume becoming rather scientific contributed books (Table 2). These publications were still accompanied with $50 \mathrm{k}$ geological maps, but the emphasis was on the book content.

\subsection{Maps for specialists}

Geological maps and geological literature were hardly accessible for the public in Hungary until the emergence of online publishing. Even the printed materials were sold only in the library of the Geological Institute in very small numbers. Second editions - after the copies of the first print was completely sold - were never published. The maps were created for specialists, and they were disseminated through the network of geological libraries as exchange copies.

The reason for this very narrow channel connecting the map makers with the map readers was largely artificially controlled: first by the censors of the state topographic data (until the 1990s), later by the geologist themselves.

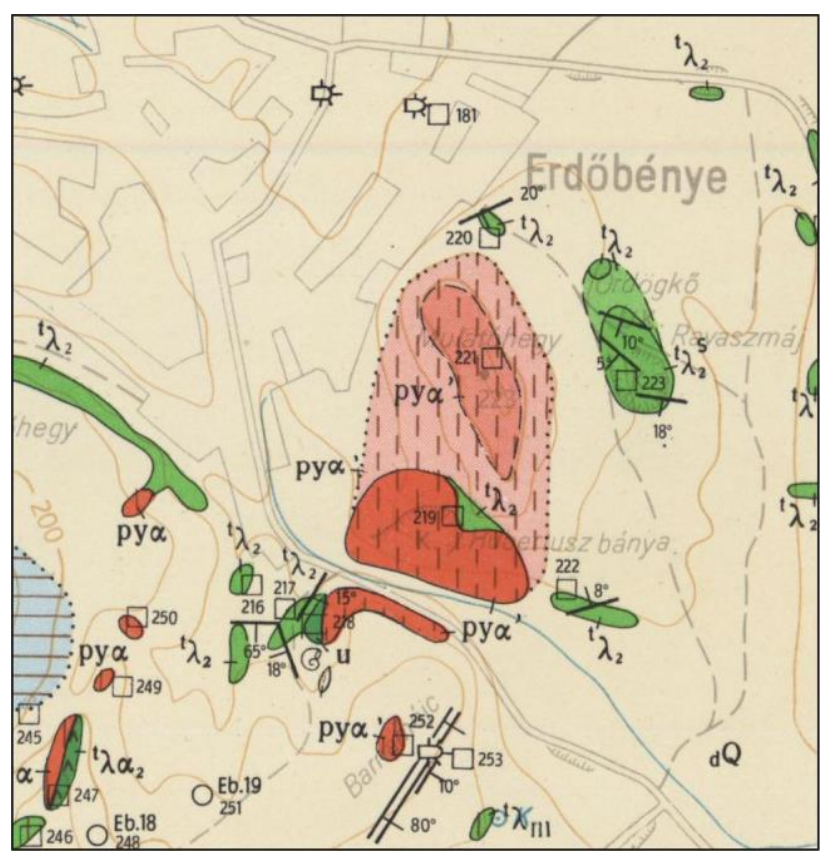

Figure 3. Excerpt of a typical $25 \mathrm{k}$ map of geological observations from the Cold War era showing Erdobbénye village: no details of topography were depicted and contour intervals were increased to $20 \mathrm{~m}$ (source: Pentelényi, 1967).

During the Cold War era state censors were watching over the use of topographic data starting from the field use of military-grade maps, through the publication as the background information for thematic maps, and ending with the restriction of selling the resulted cartographic material. Since most of the large-scale Hungarian geological maps were compiled during this era (see Table 1.) the strict ban to depict detailed topographic information generated a habit of omitting such map-data categories on the geological maps for a whole generation of geologistcartographers. The resulted maps neither contained sufficient topographical information, nor were ergonomic enough for field use (Figure 3).

Geologists working on the field had to use at least two (or rather three) maps if they wanted to find certain geological phenomena: the geological map, a military-grade topographic map, and optionally a hiking map. In short: geological maps were not suitable for field use, despite having large-enough (10-50k) scale to unite the three above mentioned map types.

\footnotetext{
4 The mining industry in Hungary drastically recessed after the collapse of the socialist economical model in 1989 (Brada et al., 2015).
} 
The ban to depict detailed topographic information on maps was ceased in 1990, but the map-compilation habits of the Hungarian geologists persisted long after this date.

\subsection{Building databases}

In the 1980s a new topographic map series was available for civil use - including scientific maps - for the whole country in 10-200k scales. Using the new Uniform Hungarian National Grid, a countrywide geological map series in $100 \mathrm{k}$ was planned and the standardization of the geological terminology of the formations has started (Gyalog, 2004). Also, from the 1980s the use of information technology infiltrated into the geosciences, and after the drastic recession in 1989, the shrunk personnel of the state geological institute, by struggling to maintain the remaining mapping projects, concentrated on building the first countrywide geological GIS (Pentelényi \& Síkhegyi, 2010). The uniform map keys - each of them as database records - were primarily designed for the $100 \mathrm{k}$ map series, but the database structure was suitable to extend the indexing system for other (larger) scales (Császár, 1997). The standardization included not only the map keys, but also the borehole data archives, providing a uniform 3D geological database (Turczi, 2004).

The geological indexing system - derived from a maintained database - was adopted for most of the published geological maps from 1996 onwards. The exceptions were mainly those, where the level of generalization was higher due to the smaller than $100 \mathrm{k}$ scale.

\subsection{The latest synthesis of geological information}

The geological database-building in the 1990s concentrated on generalized data; the first-hand field observations were not digitized. The original descriptions and categories of observation maps and boreholes were manually standardized to serve as the base of the $100 \mathrm{k}$ geological map series of Hungary.

The 100k map was published in 2005; it aimed to serve as the base data for other geosciences and for the newly venturing industrial research companies. Being the most detailed geological map covering the whole country, the firms were interested in buying it together with the borehole database. This need initiated the business model to sell geological data for the public. Unfortunately the inconsistencies between the two pieces of database (boreholes and map), and the leakage of the data turned down this interest soon, but the business model persisted in the GMA preparing the launch of the web-map era.

\section{Web maps and the new millennium}

Although, the 100k geological map of Hungary is available as a CD-atlas and as plotted tiles with map keys and other usual elements on each of the 88 tiles, its most common use-case is via the wms (web map service) server. A simple booklet with short explanations of the geological formations was published in paper format (Gyalog \&
Síkhegyi, 2005), returning to the tradition of keeping the emphasis on the cartographic material instead of the written one.

A new era of geological maps has started, and several maps followed the $100 \mathrm{k}$ series on the web map service of the Geological Institute. Some database was also published as wfs (web feature service), but compared to the raster-type format of the wms protocol, this publishing method was (and is) subordinate. The reason is the fear to lose interest on the data. Providing free state-owned data instead of selling it is still not common in Hungary.

\subsection{Digital geological mapping}

From the start of the new millennium the geological mapping technique slowly started to change in Hungary. The use of GPS became a routine during the mapping campaigns, and the handheld devices to $\log$ field observations as database records became familiar to the field geologists (Kercsmár et al., 2014). Yet, the classic way of making handwritten notes in notebook, persisted (and still persists).

From this time on, not just the generalized, but the fieldmaps were digitized - sometimes by the geologists themselves - and the GIS was built on the scale of observations, providing the possibility of spatial queries and to print edited materials shortly after the fieldwork. Based on the experiences of field geologist in several mapping campaigns, a database structure was developed for storing the field notes in both practical and ergonomic ways (Albert et al., 2012).

To reduce the time of data shearing between the professionals, the technique of an xml-type database management system (the Geonucleus) was developed (Albert, 2016). By the time the desktop-application was finished, the change of state GMA halted the application development ${ }^{5}$. Because of the same reason, the digital geological mapping (DGM), was not implemented as methodology at the geological mapping campaigns. However, the DGM remains present in Hungary in the academic sector providing best practice experience for the students at universities and also maintaining the knowledge base until the GMA is ready to implement it again.

\subsection{Geological maps for the public}

In 2010 the second edition of a geological cartographic material was published: The Geological Atlas of Hungary for Tourists (Budai \& Gyalog, 2010). This was the first (and the last) cartographic material, in the history of the Geological Institute after the WW2, which reached a second edition. The idea of the atlas was a perfect timing because the news of the 100k geological map already reached a larger audience, and the global "GEO" community started to be consciously aware of the geological heritage. The latter is manifested in 2006 with the establishment of the first Hungarian Geopark, which

Institute which inherited its responsibilities as a GMA, but not

its projects.
${ }^{5}$ In 2012 the Geological Institute of Hungary was terminated and many of its staff left or were not employed in the Geophysical 
includes the territory of the Bakony Mountains and the Balaton Uplands (BBG, 2018).

The popularity of this atlas proved the earlier hypothesis that not only the professionals, but the general public would read geological maps if the legend is suited to their level of knowledge (Hose, 1996).

The geological community in Hungary is in the process to accept the concept of geoheritage and geotourism. A scientific "ProGEO" section was already established within the Hungarian Geological Society in 2010, the UNESCO and the Ministry of Agriculture initiated a program to build the cadastre of the protected geosites ${ }^{6}$, and researchers started to focus on the area of geosite assessment. Even firms - other than the state GMA ventured into publishing geotourist maps ${ }^{7}$ (Figure 4).

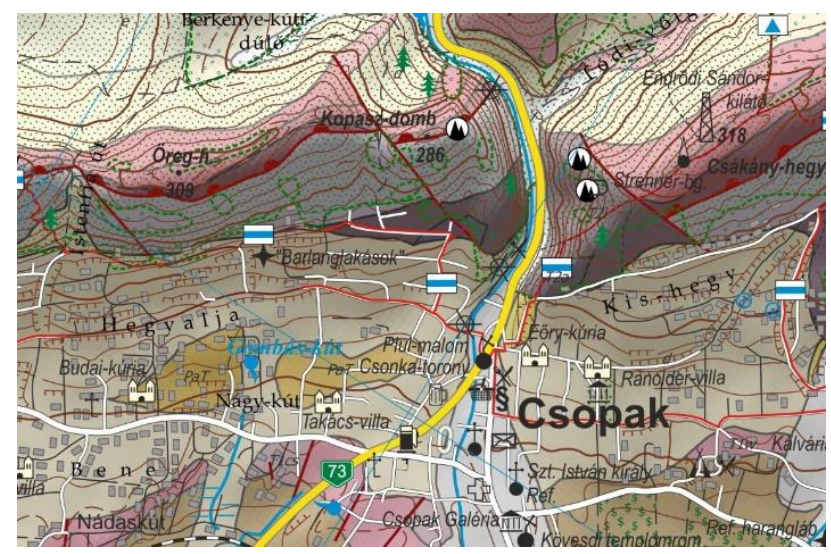

Figure 4. Excerpt of the first geological walking map in Hungary using both geological and hiking map symbols (Albert et al., 2018).

\section{Conclusions}

Digital maps in general, became part of life. This tendency includes the geological maps, and by setting up map servers to provide geological information for the public, the Hungarian state authority of geological mapping follows the flow. However, there is another tendency: the users of geological maps is changing from professionals towards the wider audience. The needs of the new audience differs from the needs of the professional community, and ideally both can be satisfied by publishing a variety of cartographic materials of the same area with different layout and legend. Since in Hungary this is not a priority of the state GMA, the geological map-making will eventually shift to external firms.

Nowadays, in Hungary, the geological mapping campaigns are revisiting those regions, where geological observations were already made, and with shrinking budget and personnel, it will take decades to finish them. Although the campaigns may bring new scientific results, the contributed scientific volumes with map inlets will only tell something for the specialists. The new audience expects, new - more detailed - cartographic materials in

${ }^{6}$ Geosites are natural landmarks that are unique from geological or geomorphological aspects. shorter time, and by the time the mapping campaign is finished, it is possible that an external firm already compiled and published a geotourist map of the area from the previously published geological materials.

With geotourism, a huge sector of economy: the tourism stepped into the realm of the geological environment. If the increasing demand of new and exotic places as destinations once drives the investors' attention to the geosites, a way of geo-communication has to be developed which is currently new to the Hungarian geologists.

Maps always played important role in geo-communication and not only the specialists, but people of the larger audience are also sensitive to them. Geotourist maps will very likely be more popular genre in the future than traditional geological maps, and in Hungary this will probably involve new map publishing firms.

\section{References}

Albert, G. (2016). Geonucleus, the freeware application for managing geological mapping data in GIS. In EGU General Assembly Conference Abstracts (Vol. 18, p. 5639).

Albert, G., Csillag, G., Fodor, L., \& Zentai, L. (2012). Visualisation of Geological Observations on Web 2.0 Based Maps. In Maps for the Future (pp. 165-178). Springer, Berlin, Heidelberg.

Albert, G., Pál, M., \& Schwarcz, Gy. (2018). Geological hiking map of the surroundings of Csopak. 1:30 000, Schwarcz Map

Balogh, K., Erdélyi, M., Kretzoi, M., Rónai. A., Schréter, Z., Sümeghy, J., Szebényi, L., Szentes, F., Szőts, E., Urbancsek, J. (1956). Geological map of Hungary 1:300 000, Geological Institute of Hungary, Budapest.

BBG, (2018). Bakony-Balaton Geopark: an introduction. http://www.geopark.hu/en/home/bakony-balatongeopark/introduction, [accessed: 2018. 11. 24.]

Beudant, F. S. (1823). Travels in Hungary, in 1818 (Vol. 9, No. 50). R. Phillips.

Böckh, J., Koch, A., Pethö, Gy., Telegdi-Roth, L., Schafarzik, F., Szontágh, T. (1896). Geologische Karte von Ungarn. Map, scale: 1:1 million. Hungarian Geological Society, Budapest.

Brada, J.C., Singh, I., Török, Á. (2015). Firms Afloat and Firms Adrift: Hungarian Industry and Economic Transition. Routledge, London. p. 31.

Brezsnyánszky, K. (1996). Austro-Hungarian geological mapping before 1869. In: Lobitzer \& Dudich (eds): Advances In Austrian-Hungarian Joint Geological Research, Budapest, pp 25-32.

Budai, T., \& Gyalog, L. eds. (2010). Geological map of Hungary for tourists. Geological Institute of Hungary, Budapest, 276. 
Compton, R.R. (1985). Geology in the Field. - Wiley, New York, 398.

Császár, G. ed. (1997). Basic lithostratigraphic units of Hungary, charts and short descriptions. Geological Institute of Hungary, Budapest, 114.

Dean, D. R. (1992). James Hutton and the history of geology. Cornell University Press.

Eyles, V. A. (1972). Mineralogical maps as forerunners of modern geological maps. The cartographic journal, 9(2), 133-135.

Gábris, Gy., Pécsi, M., Schweitzer, F., Telbisz, T. (2018). Relief. In: Kocsis, K. (chief ed.): National Atlas of Hungary: natural environment. Budapest, MTA CSFK Geographical Institute. pp. 42-57.

Galambos, Cs. (2009). History of the Hungarian Geological Maps-An Overview from the 18th Century to Nowadays. In Gartner, G., Ortag, F., (eds.) Cartography in Central and Eastern Europe. Springer, Berlin, Heidelberg. 497-508.

Gyalog, L. (2004). A földtani térképek jelkulcsrendszere mint a földtudományi adatbázisrendszer alapja. [Key system of geological maps as the base of a geoscientific database], $\mathrm{PhD}$ thesis, Pécs University, p. 65

Gyalog, L., \& Síkhegyi, F. eds. (2005). Geological map of Hungary (1: 100 000). Geological Institute of Hungary, Budapest, 188.

Hose, T.A. (1996). Geotourism, or can tourists become casual rock hounds? In Bennett, M. R., \& Doyle, P. (eds.) Geology on your doorstep. The Geological Society, London, 207-228.

Jankó, A. (2018). Military topographic maps by 1945. In Buga, L. (ed.): 100 years of Hungarian military mapping 1919-2019. Zrínyi, Budapest 2018. pp. 113-140.

Kercsmár, Zs., Budai, T., Csillag, G., Selmeczi, I., Lantos, Z., Babinszki, E., Maros, Gy. (2014). The classical geological mapping of economic, social and scientific significance. (in Hungarian with English abstract) Annual report of the Geological Institute of Hungary 2013, 165-176.

Kertai, Gy. (1957). Thickness of the post-Sarmatian sediments in Hungary. (1:1 500 000). Földtani Közlöny 87, 4, 1957. Budapest 1956.

Kóródi, E., Bartos-Elekes, Zs., Rus, I., \& Haidu, I. (2016). Cartographic analysis of some old Transylvanian geological maps from the second half of the nineteenth century. Acta Geodaetica et Geophysica, 51(3), 405-419.

Kretschmer, I., Dörflinger, J., \& Wawrik, F. (2004). Österreichische Kartographie. Wiener Schiften zur Geographie und Kartographie, 15.

Kreybig, L. (1937). The survey, analytical and mapping method of the Hungarian Royal Institute of Geology. M. Kir. Földtani Intézet Évkönyve, 31: 147-244.

Lóczy, L. sr., Papp, K. (1922). Geological Map of Hungary. (1: 900 000). Budapest.

Lyell, C. (1834). Principles of geology, being an attempt to explain the former changes of the Earth's surface, by reference to causes now in operation. London: John Murray. Vol. 1.

Oldroyd, D. R., \& Grapes, R. H. (2008). Contributions to the history of geomorphology and Quaternary geology: an introduction. Geological Society, London, Special Publications, 301(1), 1-17.

Pásztor, L., Szabó, J., Bakacsi, Z., Matus, J., \& Laborczi, A. (2012). Compilation of 1: 50,000 scale digital soil maps for Hungary based on the digital Kreybig soil information system. Journal of maps, 8(3), 215-219.

Pentelényi L. (1967). Erdőbénye. Map of geological observations, 1:25000. Geological map series of the Tokaj Mountains, Geological Institute of Hungary, Budapest

Pentelényi, A., \& Síkhegyi, F. (2012). Topographic backgrounds of geological maps in Hungary. Annual report of the Geological Institute of Hungary 2010, 8195.

Renevier, E., (1881). Rapport sur l'unification des procédés graphiques en géologie. Imp. Fava et Garagnani, Bologne, pp. 77-113.

Rudwick, M. J. (1976). The emergence of a visual language for geological science 1760-1840. History of science, 14(3), 149-195.

Szabó, B. (2018). Technical and technological reforms (1960-1980). In Buga, L. (ed.): 100 years of Hungarian military mapping 1919-2019. Zrínyi, Budapest 2018. pp. 203-231.

Szabó-Kele, G., Hernádi, H., Makó, A. eds. (2010). Bridging the centuries 1909-2009: Historical gallery. Soil Protection Foundation, Budapest, 52 p.

Tóth-Makk, Á. ed. (1994). 125 years Hungarian Geological Survey, Budapest, 188.

Townson, R. (1797). Travels in Hungary, with a short account of Vienna in the year 1793. GG and J. Robinson.

Turczi, G. (2004). Setting up the spatial geological model of Hungary - databases on the intranet and internet. Annual report of the Geological Institute of Hungary 2004, 125-130.

Várallyay, G. (1989). Soil mapping in Hungary. Agrokémia és Talajtan, 38, 696-714.

Vitális, Gy. (1993). Early geological maps published independently or as inserted books of the Hungarian Geological Institute 1920-1944. Annual Report of the Hungarian Geological Survey 1991, 381-394.

VNRH (2018): Voluntary National Review of Hungary on the Sustainable Development Goals of the 2030 Agenda. Ministry of Foreign Affairs and Trade of Hungary, 83 p.

von Hauer, F. (1867). Geologische Übersichts-Karte der Österreich-Ungarischen Monarchie. (Scale 1:576,000). Wien.

Zentai, L. (2018). The Transformation of Relief Representation on Topographic Maps in Hungary: From Hachures to Contour Lines. The Cartographic Journal, 55(2), 150-158. 